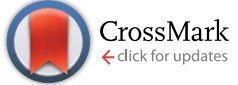

Cite this: RSC Adv., 2017, 7, 3398
Received 31st October 2016 Accepted 26th November 2016

DOI: $10.1039 / c 6 r a 26104 c$

www.rsc.org/advances

\section{Rhodium(I) diphenylphosphine complexes supported on porous organic polymers as efficient and recyclable catalysts for alkene hydrogenation $\dagger$}

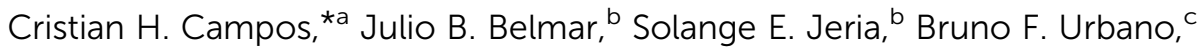 \\ Cecilia C. Torres ${ }^{d}$ and Joel B. Alderete ${ }^{b}$
}

\section{Introduction}

Hybrid materials have become an excellent alternative for use as a support and/or catalyst in hydrogenation processes for fine chemicals because their organic/inorganic nature confers the ability to be used in very specific processes..$^{1-5}$ Some examples of hybrid materials are metal organic frameworks (MOFs), ${ }^{6}$ hybrid-

\footnotetext{
${ }^{a}$ Departamento de Físico-Quimica, Facultad de Ciencias Quimicas, Universidad de Concepción, Concepción, Chile.E-mail: ccampos@udec.cl

${ }^{b}$ Departamento de Química Orgánica, Facultad de Ciencias Químicas, Universidad de Concepción, Concepción, Chile

'Departamento de Polímeros, Facultad de Ciencias Quimicas, Universidad de Concepción, Concepción, Chile

${ }^{d}$ Departamento de Ciencias Quimicas, Facultad de Ciencias Exactas, Universidad Andres Bello, Sede Concepción, Autopista Concepción-Talcahuano 7100, Talcahuano, Chile
}

$\dagger$ Electronic supplementary information (ESI) available. See DOI: $10.1039 / \mathrm{c} 6 \mathrm{ra} 26104 \mathrm{c}$ polymer resins, ${ }^{7,8}$ clay-polymer composites, ${ }^{9}$ among others. Especially in the use of synthetic hybrid-polymeric materials, Merrifield resins arise as an attractive type of support for the covalent immobilization of coordination metal complexes catalysts for selective hydrogenation ${ }^{10,11}$ due to their versatile surface functionalization. The main disadvantage of Merrifield materials is its low surface area which restrict the accessibility at the reactive moieties introduced into them as a result of the crosslinking density of the polymer matrix. ${ }^{5}$

In recent years, suspension polymerization is used to produce crosslinked-polymers with a controllable pore structure and a high surface area compared to Merrifield resins. ${ }^{12-14}$ These materials contain well-developed micropores and mesopores, therefore should decrease the diffusion limitations and significantly improve the accessibility to the reactive pending groups and produce highly dispersed catalysts. ${ }^{15-17}$ In this way, Canali et al. ${ }^{18}$ have reported a porous polystyrene/ polymethacrylate-based resin with supported Jacobsen's chiral 
Mn-saliciden-ethylenediamine complexes for alkene enantioselective oxidation. Drake et al. have explored the use of vinylbenzyl chloride-based resins which have been aminated using $N, N, N^{\prime}$-trimethylethylenediamine to produce coordinated $\mathrm{Pt}$ (II) catalysts for the hydrosilylation of 1-octene using methyldichlorosilane at room temperature. ${ }^{19}$

Heterogeneous metal catalysts are widely used in the hydrogenation of alkenes. ${ }^{\mathbf{2 0 , 2 1}}$ Liquid-phase hydrogenation of unsaturated organic compounds with $\mathrm{C}=\mathrm{C}$ bond typically involve transition metals such as $\mathrm{Pd}, \mathrm{Pt}, \mathrm{Rh}, \mathrm{Ni}, \mathrm{Ru}$, among others. Palladium supported on carbonaceous materials is widely used as a catalyst in this reaction. ${ }^{22}$ However, problems in chemoselectivity are occasionally encountered when the substrate contains functional groups sensitive under the reaction conditions of hydrogenation. ${ }^{23-25}$ To address this issue, rhodium is the most employed noble metal as homogeneous catalyst for alkene hydrogenation reactions because possess the ability to activate the hydrogen molecule to provide a specific transfer of a hydride atom to the alkene moiety during the catalytic cycle. ${ }^{26,27}$ Phosphines molecules are used as ligands in the hydrogenation of several types of olefins by Rh catalysts ${ }^{\mathbf{4 , 2 8 , 2 9}}$ and the literature contains several reports about the hydrogenation ability of cationic $\left[\mathrm{Rh}(\text { diene })\left(\mathrm{PR}_{3}\right)_{2}\right]^{+}$complexes under relatively mild reaction conditions. ${ }^{27,30}$ From this background, we are interested in investigating the performance of diphenylphosphine-rhodium complexes based immobilized on the porous polymeric-resins in the hydrogenation of the styrene and its derivates. The aim of the present work is the design and synthesis of new polymeric-resins having functional moieties able to covalently bond $\mathrm{Rh}(\mathrm{I})$ diphenylphosphine catalysts. For this purpose we used two co-monomers derived from $\mathrm{N}, \mathrm{N}$ bis(chloroethyl)amine: $\quad N, N$-bis(2-chloroethyl)-2-propen-1-amine (Alk-N $\left.\left(\mathrm{CH}_{2} \mathrm{CH}_{2} \mathrm{Cl}\right)_{2}\right)$ and $N, N$-bis(2-chloroethyl)acrylamide (Acy$\left.\mathrm{N}\left(\mathrm{CH}_{2} \mathrm{CH}_{2} \mathrm{Cl}\right)_{2}\right)$ as shown in Scheme 1. In fact, the polymer synthesis procedure including chloroethyl-monomers allows obtaining porous polymer-supports with an improved accessibility to its functionalities. Subsequently diphenylphosphine ligands were prepared into the polymer-resins and formed cationic rhodium(I) complexes, which were employed in heterogeneous liquid phase styrene hydrogenation. Herein, the best catalytic system was studied in seven recycles studies. Finally, the catalytic hydrogenation of a series of $m$-substituted styrene substrates was investigated and the catalytic data were subjected to Hammett treatment.

\section{Experimental section}

\subsection{Materials}

All of the air-sensitive reactions were performed under an inert atmosphere $\left(\right.$ Ar or $\mathrm{N}_{2}$ ) in a Schlenk flask. Tetrahydrofuran (THF, Merck $\left.{ }^{\circledR}\right)$ and toluene (Merck $\AA$ ) were dried in metallic sodium/ benzophenone, dichloromethane $\left(\mathrm{CH}_{2} \mathrm{Cl}_{2}, 99.8 \%\right.$ anhydrous, Aldrich $\left.{ }^{\circledR}\right)$ and acetonitrinile $\left(\mathrm{CH}_{3} \mathrm{CN} 99 \%\right.$ Merck $\left.{ }^{\circledR}\right)$ were dried as required by contact with calcium hydride (Sigma ${ }^{\circledR}$ ) for several days and then distilled immediately before use. Triethylamine (TEA 95\% Aldrich ${ }^{\circledR}$ ), methyl acrylate (MA, 99\% Aldrich ${ }^{\circledR}$ ) and divinylbenzene (DVB, technical grade, 80\%
Aldrich $\left.{ }^{\circledR}\right)$ were distilled at a reduced pressure prior to use: TEA with $\mathrm{CaH}_{2}$, both MA and DVB in presence of $p$-tert-butylcatechol as polymerization inhibitor. 2,2'-Azobis(isobutyronitrile) (AIBN, Aldrich $\left.{ }^{\circledR}\right)$ was recrystallized from methanol. The compounds allyl bromide (98\% Aldrich®), acryloyl chloride (99\% Merck®), potassium diphenylphosphide $\left(\mathrm{KPPh}_{2}\right.$ solution $0.5 \mathrm{M}$ in THF, Aldrich $\left.{ }^{\circledR}\right)$, bis(1,5-cyclooctadiene)rhodium(I) tetrafluoroborate (Aldrich ${ }^{\circledR}$ ), diisopropylethylamine (DIEA, 99\% Merck®), bis(2chloroethyl)amine hydrochloride (98\% Aldrich $\left.{ }^{\circledR}\right)$, anhydrous sodium sulfate $\left(\mathrm{Na}_{2} \mathrm{SO}_{4}\right.$, Merck $\left.{ }^{\circledR}\right)$, hydrochloric acid ( $\mathrm{HCl}, 37 \%$ Merck $\left.{ }^{\circledR}\right)$, sodium chloride ( $\mathrm{NaCl}$, Merck $\left.®\right)$, sodium hydroxide (NaOH, Merck ${ }^{\circledR}$ ), hydroxyethylcellulose (average $M_{\mathrm{w}} 250000$, Aldrich $\left.{ }^{\circledR}\right)$, styrene (98\%, Aldrich $\left.®\right), m$-nitrostyrene (98\%, Aldrich $₫), m$-chlorostyrene (99\%, Aldrich $®), m$-methylstyrene (99\%, Aldrich $\left.{ }^{\circledR}\right), m$-aminostyrene (99\%, Aldrich $\left.{ }^{\circledR}\right)$ and the solvent $n$-hexanes (PA, Merck®) were used as received. The Scheme 1 shows the synthetic rout employed to prepare the immobilized catalysts.

\subsection{Co-monomers synthesis}

$\mathrm{N}, \mathrm{N}$-Bis(2-chloroethyl)-2-propen-1-amine $\quad\left(\right.$ Alk- $\mathrm{N}\left(\mathrm{CH}_{2} \mathrm{CH}_{2}\right.$ Cl) $)_{2}$ ). A solution of bis(2-chloroethyl)amine hydrochloride in dry in $\mathrm{CH}_{3} \mathrm{CN}$ solution $\left(50 \mathrm{~mL}, 0.22 \mathrm{~mol} \mathrm{~L}^{-1}\right)$ was slowly added (10 $\mathrm{min})$ to a dry $\mathrm{CH}_{3} \mathrm{CN}(10 \mathrm{~mL})$ solution of the allyl bromide $1.4 \mathrm{~mL}$ (17 mmol) and DIEA (40 mmol). The mixture was stirred for $12 \mathrm{~h}$ at room temperature. Removal of solvent led to a solid which was dissolved in $\mathrm{CH}_{2} \mathrm{Cl}_{2}$ and washed with an $\mathrm{HCl} 0.1 \mathrm{~mol}$ $\mathrm{L}^{-1}(50 \mathrm{~mL} \times 2)$ and water $(50 \mathrm{~mL} \times 2)$. The organic layer was dried overnight in anhydrous $\mathrm{Na}_{2} \mathrm{SO}_{4}$. Finally, removal of solvent from the filtrate led to a yellowish viscous compound with $58 \%$ yield. ${ }^{1} \mathrm{H}$ NMR $\left(\mathrm{CDCl}_{3}\right): \delta 2.83\left(\mathrm{t}, 4 \mathrm{H},-\mathrm{N}-\left(\mathrm{CH}_{2}-\right)_{2}\right), 3.16$ $\left(\mathrm{d}, 2 \mathrm{H},-\mathrm{CH}_{2}-\mathrm{N}-\right), 3.46$ (t, $\left.4 \mathrm{H},-\left(\mathrm{CH}_{2}-\mathrm{Cl}\right)_{2}\right), 5.12$ (dd, $2 \mathrm{H}, \mathrm{CH}_{2}=$ $\mathrm{CH}-)$, $5.76\left(\mathrm{~m}, 1 \mathrm{H},=\mathrm{CH}-\mathrm{CH}_{2}-\right) ;{ }^{13} \mathrm{C} \mathrm{NMR}\left(\mathrm{CDCl}_{3}\right): \delta 42.1$ (s, C5 $\pm \mathrm{C} 7), 55.9$ (s, C4 \pm C6), 57.8 (s, C3), 118.0 (s, C1), 134.8 (s, C2).

$\mathrm{N}, \mathrm{N}$-Bis(2-chloroethyl)acrylamide $\quad\left(\mathrm{Acy}-\mathrm{N}\left(\mathrm{CH}_{2} \mathrm{CH}_{2} \mathrm{Cl}\right)_{2}\right) . \quad \mathrm{A}$ solution of the acryloyl chloride in dry $\mathrm{CH}_{2} \mathrm{Cl}_{2}(50 \mathrm{~mL}, 0.11 \mathrm{~mol}$ $\left.\mathrm{L}^{-1}\right)$ was added dropwise $(0.5 \mathrm{~h})$ to a stirred, ice-cooled solution of bis(2-chloroethyl)amine hydrochloride (1.0 g, $5.6 \mathrm{mmol}$ ) with TEA $(2.0 \mathrm{~mL}, 11.2 \mathrm{mmol})$ in dry $\mathrm{CH}_{2} \mathrm{Cl}_{2}(50 \mathrm{~mL})$. The mixture was further stirred for $2 \mathrm{~h}$. The reaction mixture was washed with $\mathrm{HCl} 0.1 \mathrm{~mol} \mathrm{~L}^{-1}(50 \mathrm{~mL} \times 2)$ and water $(50 \mathrm{~mL} \times 2)$. The organic layer was dried overnight in anhydrous $\mathrm{Na}_{2} \mathrm{SO}_{4}$. Finally, removal of solvent from the filtrate led to colorless viscous with 90\% yield. ${ }^{1} \mathrm{H}$ NMR $\left(\mathrm{CDCl}_{3}\right): \delta 3.24\left(\mathrm{t}, 4 \mathrm{H},-\mathrm{N}-\left(\mathrm{CH}_{2}-\right)_{2}\right), 3.64(\mathrm{t}$, $\left.4 \mathrm{H},-\left(\mathrm{CH}_{2}-\mathrm{Cl}\right)_{2}\right), 5.58$ (dd, $1 \mathrm{H}, \mathrm{CH}_{2}=\mathrm{CH}-$ ), 6.34 (dd, $1 \mathrm{H}, \mathrm{CH}_{2}=$ $\mathrm{CH}-)$; $6.62(\mathrm{~m}, 1 \mathrm{H},=\mathrm{CH}-\mathrm{CO}-) ;{ }^{13} \mathrm{C} \mathrm{NMR}\left(\mathrm{CDCl}_{3}\right): \delta 42.7(\mathrm{~s}, \mathrm{C} 5 \pm$ C7), 52.9 (s, C4 \pm C6), 126.2 (s, C1), 131.0 (s, C2), 162.8 (s, C3).

\subsection{Synthesis of porous polymer-resins}

Porous polymer-resins were synthesized via suspension polymerization using a modified procedure reported in detail by Wei et al. ${ }^{14}$ The co-monomers (MA and $\mathrm{x}-\mathrm{N}\left(\mathrm{CH}_{2} \mathrm{CH}_{2} \mathrm{Cl}\right)_{2}$ where $\mathrm{x}$ : Alk or Acy) were first mixed well with the porogen (toluene) and DVB as crosslinker, in mass ratio $2: 39: 60$, to form an organic phase in which the initiator, AIBN, was added (1 wt $\%$ monomers-based). The organic phase mixture was then added, 


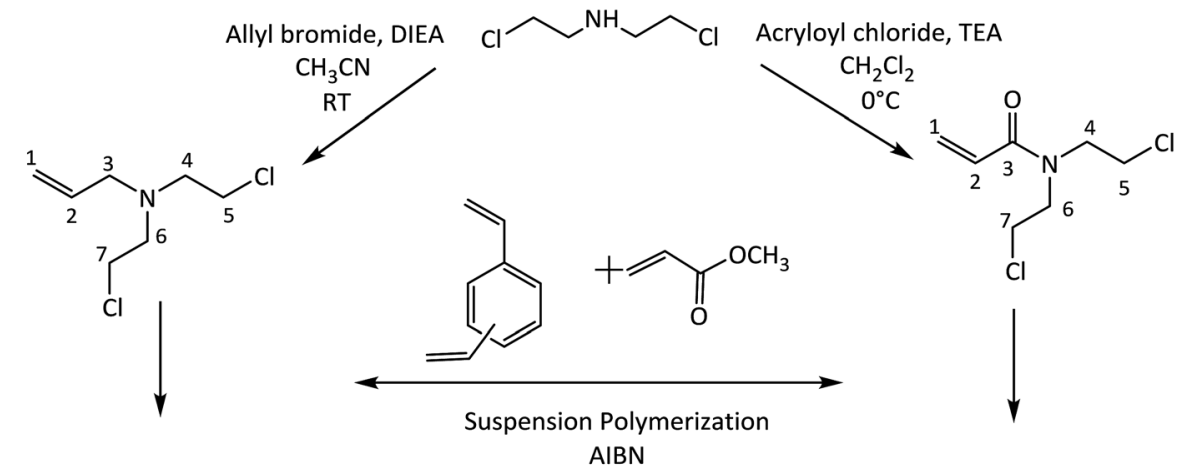

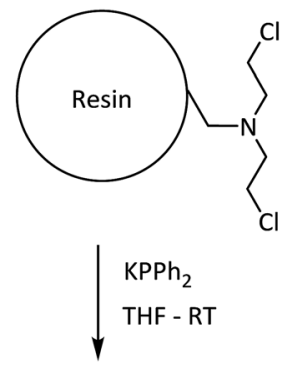

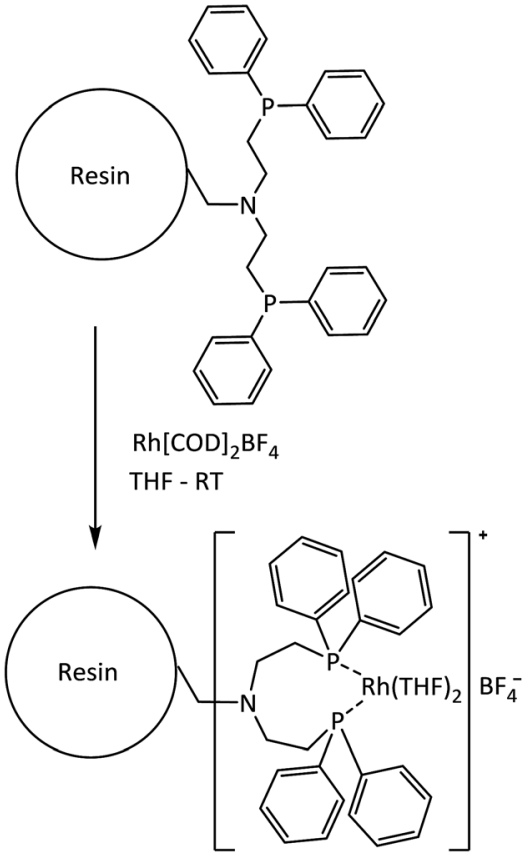

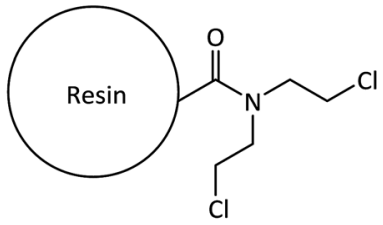

$\mathrm{KPPh}_{2}$ THF - RT

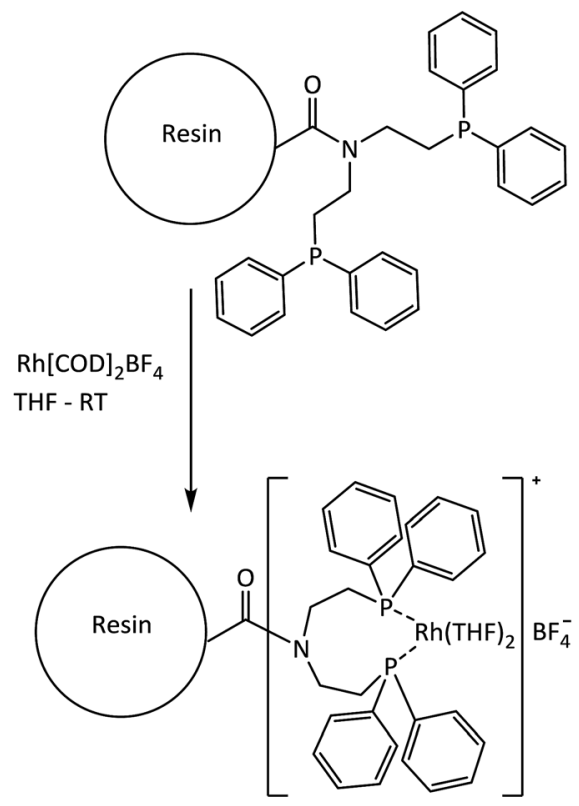

Scheme 1 Immobilization rout for the Rh-based catalysts.

at a $1: 3$ ratio $(\mathrm{v} / \mathrm{v})$, to the aqueous phase containing $0.2 \%$ hydroxyethyl cellulose and $20 \% \mathrm{NaCl}$, and the polymerization was allowed to proceed at $70{ }^{\circ} \mathrm{C}$ and $85-90{ }^{\circ} \mathrm{C}$ for 14 and $4 \mathrm{~h}$, respectively. The resulting $\mathrm{MA} / \mathrm{x}-\mathrm{N}\left(\mathrm{CH}_{2} \mathrm{CH}_{2} \mathrm{Cl}\right)$ co-polymer materials were washed with hot water and extracted thoroughly with acetone in a Soxhlet apparatus, and the acetoneswollen solid were finally dried in vacuum at $80{ }^{\circ} \mathrm{C}$.

\subsection{Phosphination of porous polymer-resins and catalyst synthesis}

Initially the a suitable amount of $\mathrm{MA} / \mathrm{x}-\mathrm{N}\left(\mathrm{CH}_{2} \mathrm{CH}_{2} \mathrm{Cl}\right)$ copolymer materials was charged into a cooled $\left(0{ }^{\circ} \mathrm{C}\right)$ Schlenk flask (100 mL) containing dry and degasified THF (50 mL). Under dry $\mathrm{N}_{2}$, the required amount of $\mathrm{KPPh}_{2}$ was added and the mixture stirred for $2 \mathrm{~h}$. The mixture was then left stirring for $48 \mathrm{~h}$, at room temperature, under $\mathrm{N}_{2}$ gas. The quantity of $\mathrm{KPPh}_{2}$ used were such that a $1: 2$ molar ratio of porous polymer-resin$\mathrm{N}\left(\mathrm{CH}_{2} \mathrm{CH}_{2} \mathrm{Cl}\right)$ functionality : $\mathrm{KPPh}_{2}$. The reaction was quenched in degasified $\mathrm{H}_{2} \mathrm{O}(100 \mathrm{~mL})$, filtered and the solids washed with both degasified $\mathrm{H}_{2} \mathrm{O}$ and THF, respectively. Each phosphinated resin $(2.0 \mathrm{~g})$ was placed in a Schlenk flask with dry and degasified THF $(20 \mathrm{~mL})$ and mixed with a suitable amount of $\left[\mathrm{Rh}(\mathrm{COD})_{2}\right] \mathrm{BF}_{4}$ dissolved in dry and degasified THF $(5 \mathrm{~mL})$. The quantity of the rhodium used was stoichiometrically equivalent 
to the diphenylphosphine content of the phosphinated resin used, and was calculated from the values detailed in Table 1. The mixture was stirred for $48 \mathrm{~h}$, at room temperature, under $\mathrm{N}_{2}$ atmosphere. Finally the obtained materials were filtered and repeatedly washed with THF, acetone and water, respectively. The light-orange materials prepared were stored in a desiccator under an $\mathrm{N}_{2}$ atmosphere prior to the activity measurements. The catalysts obtained were labeled as Rh-AlkPOL and Rh-Acy-POL for both alkylated and acylated comonomers precursors, respectively.

\subsection{Characterization}

The chemical composition of the catalysts was determined by inductively coupled plasma optical emission spectroscopy (ICP-OES, PerkinElmer 7300DV). The samples (10 mg) were chemically digested by dissolution in a mixture of $15 \mathrm{~mL} \mathrm{HCl}$ and $5 \mathrm{~mL} \mathrm{HNO}_{3}$ in an autoclave for $2 \mathrm{~h}$ at $150{ }^{\circ} \mathrm{C}$. The ${ }^{13} \mathrm{C}$ - and ${ }^{31} \mathrm{P}$-decoupled NMR spectra were obtained on a Bruker AMX-300 spectrometer (300 MHz for ${ }^{1} \mathrm{H}, 75 \mathrm{MHz}$ for ${ }^{13} \mathrm{C}$ and $121 \mathrm{MHz}$ for ${ }^{31} \mathrm{P}$ ) using trimethylsilane and $\mathrm{H}_{3} \mathrm{PO}_{4}$ as internal standards. The solid-state ${ }^{13} \mathrm{C}$ and ${ }^{31} \mathrm{P}$ CP-NMR spectra were recorded at $100 \mathrm{MHz}$ and $162 \mathrm{MHz}$, respectively, uses a Bruker AV $400 \mathrm{WB}$ spectrometer. The XRD patterns were recorded in a RigakuD/ max-2500 diffractometer with the $\mathrm{Cu} \mathrm{K}_{\alpha}$ radiation at $40 \mathrm{kV}$ and $100 \mathrm{~mA}$. The $\mathrm{N}_{2}$ adsorption-desorption isotherms at $-196{ }^{\circ} \mathrm{C}$ were performed in a Micromeritics ASAP 2010 apparatus. The specific surface areas were determined by the BET (Brunauer-Emmett-Teller) equation, using the adsorption data in the relative pressure range of 0.05 to 0.3 , and the pore-size distributions were estimated using the BJH method. The catalysts morphology was examined by the transmission electron microscopy (TEM). The X-ray photoelectron spectra (XPS) were recorded using a VG Escalab $200 \mathrm{R}$ spectrometer equipped with a hemispherical analyzer and using non-monochromatic $\mathrm{Mg} \mathrm{K} \alpha \mathrm{X}$-ray radiation $(h \nu=1253.6 \mathrm{eV})$. The binding energies (BE) were calculated with respect to the C-component of the C 1s peak fixed at $284.8 \mathrm{eV}$. The data analysis was performed with the "XPS Peak" software. The peaks were decomposed into a sum of Gaussian/Lorentzian (G/L = 90/10) after the subtraction of a Shirley-type baseline. The surface P/C, Cl/C, Rh/ $\mathrm{C}$ and $\mathrm{Rh} / \mathrm{P}$ atomic ratios were estimated from the integrated intensities of the $\mathrm{P} 2 \mathrm{p}, \mathrm{Rh} 3 \mathrm{p}, \mathrm{C} 1 \mathrm{~s}$, and $\mathrm{Cl} 2 \mathrm{p}$ lines after the background subtraction and were corrected by the atomic sensitivity factors. ${ }^{31}$

Table 1 Textural and physical properties of polymer-based supports and Rh catalysts

\begin{tabular}{lllll}
\hline & & $\mathrm{ICP}$ & \\
\cline { 3 - 5 } Sample & $S_{\text {BET }}\left(\mathrm{m}^{2} \mathrm{~g}^{-1}\right)$ & $\mathrm{Rh}^{a}(\mathrm{wt} \%)$ & $\mathrm{P}^{a}(\mathrm{wt} \%)$ & $\mathrm{Rh} / \mathrm{P}^{b}$ \\
\hline Alk-POL & 420 & - & - & - \\
Acy-POL & 380 & - & - & - \\
Rh-Alk-POL & 330 & $0.63(1.0)$ & $0.50(0.61)$ & $1.26(1.66)$ \\
Rh-Acy-POL & 270 & $0.95(1.0)$ & $0.59(0.61)$ & $1.63(1.66)$
\end{tabular}

${ }^{a}$ Nominal values in brackets. ${ }^{b} \mathrm{wt} \%$ ratio.

\subsection{Catalytic activity}

The catalytic assays of the alkenes hydrogenation were performed in a stainless steel $(100 \mathrm{~mL})$ Parr-type semi-batch reactor at a substrate concentration of $0.01 \mathrm{~mol} \mathrm{~L}^{-1}$ using methanol $(25 \mathrm{~mL})$ as the solvent and stirring at $700 \mathrm{rpm}$ under 5.0 bar of $\mathrm{H}_{2}$ pressure at $25^{\circ} \mathrm{C}$. All of the catalytic runs were conducted in the absence of external mass transfer limitations and were repeated three times for each experiment. The catalysts were in the form of fine powders $(>30 \mu \mathrm{m})$, assuming a negligible effect of pore diffusion limitations. In the catalyst mass studies, the alkene/Rh molar ratio was varied, the concentration of PPD was maintained constant, and the mass of the catalyst was modified. No significant differences in the initial reaction rates were noted upon varying the catalyst mass over the range of 0.01 to $0.07 \mathrm{~g}$ because the reaction rate was proportional to the catalyst mass, indicating that the gas-liquid and liquid-solid external mass transfer limitations were absent. ${ }^{32,33}$ The pseudo-kinetic constants $(k)$ were calculated using a pseudo-first-order kinetic model for a batch reactor under similar conditions, as reported in previous studies. ${ }^{34}$ The reactants and products were analyzed by gas chromatography and mass spectrometry using a GC-FID instrument (HP-4890) with a semi-capillary column HP-5 and $\mathrm{N}_{2}$ as the carrier gas. The recycling assays were performed by filtering the catalyst from the reaction medium. The filtered catalyst was washed three times consecutively with methanol $(50 \mathrm{~mL} \times 3)$ to clean the surface and then dried at $100{ }^{\circ} \mathrm{C}$ for $24 \mathrm{~h}$. The activity of the catalyst was monitored by the following conversion levels and selectivity:

$$
\begin{gathered}
X(\%)=\frac{[\text { alkene }]_{0}-[\text { alkene }]_{t}\left(\mathrm{~mol} \mathrm{~L}^{-1}\right)}{[\text { alkene }]_{0}\left(\mathrm{~mol} \mathrm{~L}^{-1}\right)} \times 100 \\
S(\%)=\frac{[\text { target alkene }]_{t}\left(\mathrm{~mol} \mathrm{~L}^{-1}\right)}{[\text { target alkene }]_{t}+[\text { other products }]_{t}\left(\mathrm{~mol} \mathrm{~L}^{-1}\right)} \times 100
\end{gathered}
$$

where [alkene $]_{0}$ corresponds to the initial concentration of the alkene, and [alkene $]_{t}$ is the concentration at different times. Target alkene corresponds to the hydrogenation of vinyl moiety of styrene or meta-substituted styrene substrates. The turnover frequency (TON) of the catalysts was calculated as follows:

$$
\mathrm{TON}=\frac{\text { substrate hydrogenated }(\mathrm{mol})}{\mathrm{Rh}(\mathrm{mol})}
$$

\section{Results and discussion}

\subsection{Supports and catalysts characterization}

Polymer supports were synthesized via the copolymerization of DVB with the as-prepared $N, N$-bis(2-chloroethyl)-2-propen-1amine and $N, N$-bis(2-chloroethyl)acrylamide co-monomers, respectively, as illustrated in Scheme 1 . These compound were inserted into the polymer matrices and then allow the synthesis of the catalyst systems as seen in Table 1. Both systems showed $\mathrm{N}_{2}$ adsorption-desorption isotherms with $\mathrm{H} 1$ hysteresis loop, which is a typical for mesoporous structure and cylindrical pores as shown in Fig. 1. In the same way, the catalysts isotherms 

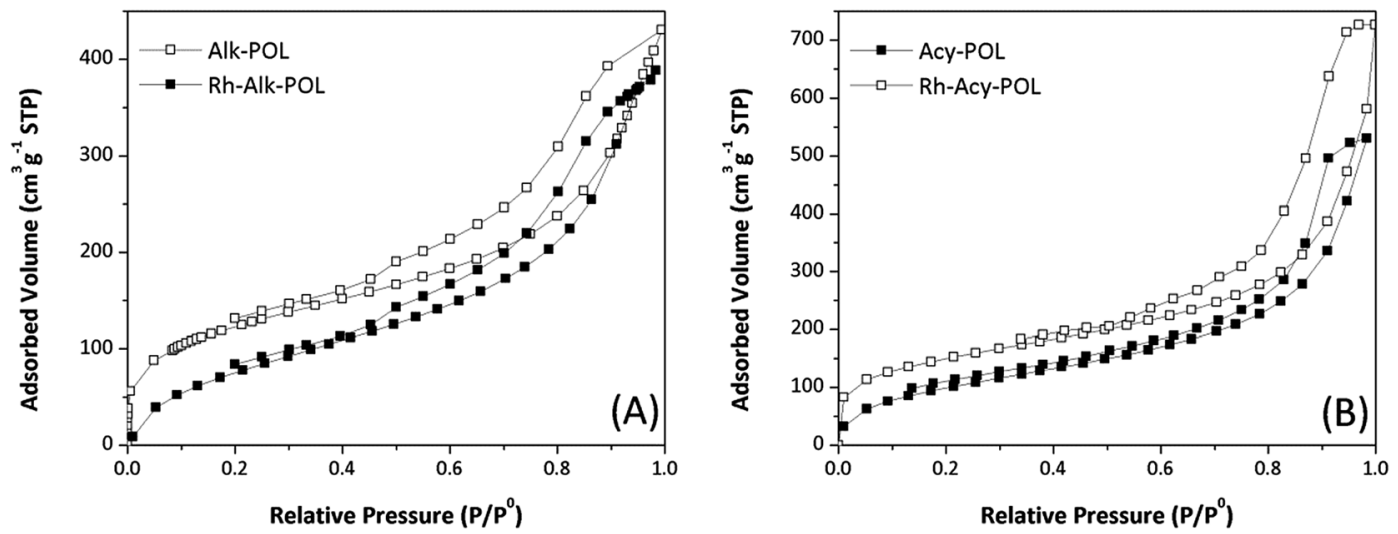

Fig. $1 \mathrm{~N}_{2}$ adsorption/desorption isotherms of supports and Rh catalysts. (A) Alk-POL based materials and (B) Acy-POL based materials.

remain a mesoporous structure of supports after the postmodification synthesis. However, the BET specific surface area of polymers and catalysts gradually decrease according to the parameters provided in Table 1 . This phenomenon is mainly due to the introduction of bulky $-\mathrm{P}(\mathrm{Ph})_{2}$ ligands and $\mathrm{Rh}$ complex that partially block the pores and reduce the adsorption of $\mathrm{N}_{2}$.

The amount of rhodium determined by ICP-OES in the RhAlk-POL fresh catalysts is $0.67 \mathrm{wt} \%$, corresponding to 65.1 $\mu \mathrm{mol}$ of complex per gram of sample, while the catalyst Rh-AcyPOL the amount is $0.95 \mathrm{wt} \%$ corresponding to $93 \mu \mathrm{mol}$ of complex per gram of sample. According to these values the Rh-Alk-POL system showed both lower Rh loading and Rh/P mass ratio. This behavior could be attributed to the uncomplete chlorine substitutions during the support's modification exhibiting a decrease in the $\left(\mathrm{Ph}_{2}\right)_{2} \mathrm{P}$ loading confirmed by XPS (vida infra). In the same way, the $\mathrm{Rh} / \mathrm{P}$ mass ratio decreases compared with the nominal value, most likely due to uncoordinated P moieties remaining from the catalyst synthesis. RhAcy-POL catalyst showed the expected Rh and P contributions indicating that the support modifications were made according to the nominal catalyst loading.

The ${ }^{13} \mathrm{C}$ and ${ }^{31} \mathrm{P}$ solid-state NMR characterization are shown in Fig. 2. For all of the systems ${ }^{13} \mathrm{C}$ NMR spectra (Fig. 2A) display the characteristic bands of the polymer backbone, $-\mathrm{CH}_{2}$ carbons from the ligands and $-\mathrm{CH}_{3}$ moiety attributed to MA methoxyl-group at chemical shifts between 20 and $60 \mathrm{ppm}$ are detected. The signals at $120-160 \mathrm{ppm}$ can be assigned to DVB crosslinker aromatic carbons. Both catalysts showed an increased contribution of the aromatics signals at $140 \mathrm{ppm}$ attributed to the presence of diphenylphosphine ligands. Finally, the signal at $184 \mathrm{ppm}$ ascribed to carbonyl contribution of MA is detected.

In ${ }^{31} \mathrm{P}$ NMR characterization (Fig. $2 \mathrm{~B}$ ) for both catalysts, a broad signal at chemical shifts between 20 and $45 \mathrm{ppm}$ is observed. In the case of system Rh-Alk-POL showed two contributions, the first one at $20.2 \mathrm{ppm}$ attributed to the presence of species of $\mathrm{P}-\mathrm{Rh}^{35}$ and the second one at $38.4 \mathrm{ppm}$ attributed to $\mathrm{P}=\mathrm{O}$ species. ${ }^{36,37}$ This result is in agreement with the lower metal loading detected by ICP-AES. It must be noted that the NMR analysis of sample Rh-Alk-POL was conducted in air atmosphere, and hence the $\mathrm{P}=\mathrm{O}$ signal appears due to the oxidation of unreacted $\mathrm{Ph}_{2} \mathrm{P}$ groups with air to produce phosphine oxide. Rh-Acy-POL catalyst showed a signal at $27.0 \mathrm{ppm}$ attributed to the coordinate $\mathrm{P}-\mathrm{Rh}$ as was reported by Román-Martínez et al. ${ }^{38}$ whereas the signal of $\mathrm{P}=\mathrm{O}$ species do not appear. These results confirm the COD ligand displacement during the catalyst synthesis providing the complex $(\mathrm{PP})-\mathrm{Rh}(\mathrm{COD}) \mathrm{BF}_{4}$ complexes on the resins surface.
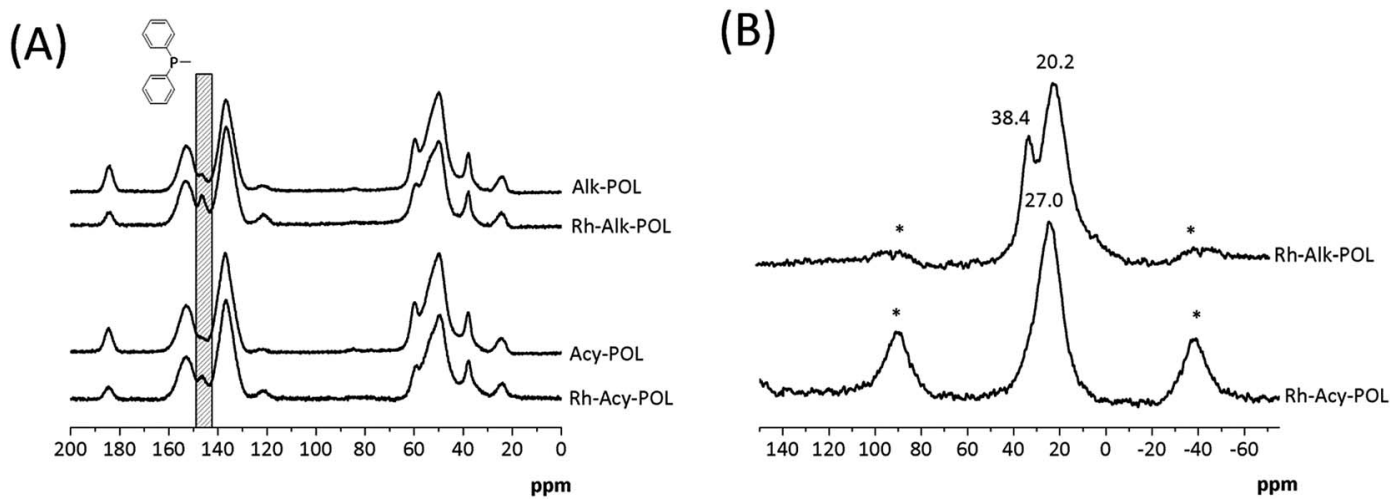

Fig. 2 Solid state NMR spectra of polymer-based supports and Rh catalysts. (A) ${ }^{13} \mathrm{C} C P / M A S$ and $(B){ }^{31} \mathrm{P} C P / M A S$ and rotational sidebands are denoted by asterisks (*). 
The XPS method has been used for qualitative characterizations of the obtained catalysts. The binding energies for Rh $3 \mathrm{~d}_{5 / 2}, \mathrm{Cl} 2 \mathrm{p}, \mathrm{P} 2 \mathrm{p}$ and $\mathrm{C} 1 \mathrm{~s}$ as well as atomic ratios of $\mathrm{Rh} / \mathrm{P}$ and $\mathrm{Cl} / \mathrm{C}$ on the surface of the samples are given in Table 2 . The Rh $3 \mathrm{~d}_{5 / 2}$ binding energies (BE) confirm the presence of Rh(I) oxidation state. ${ }^{38,39}$ During the catalysts synthesis, $\mathrm{Rh}(\mathrm{COD})_{2} \mathrm{BF}_{4}$ precursor was not oxidized providing the ligand substitution pathway. In the same way, Rh-Alk-POL system showed $\mathrm{BE}$ for $\mathrm{Cl} 2 \mathrm{p}$ at $198.2 \mathrm{eV}$ attributed to the organic chlorine contributions. In the synthesis design of Alk-POL and Acy-POL supports, a stoichiometric quantity of the comonomers (Alk-NClCl or Acy-NClCl) to produce the desire immobilized catalysts were used. However, the Rh-Alk-POL catalyst showed a remained a fraction of $\mathrm{CH}_{2}-\mathrm{Cl}$ on the surface as a consequence to an uncomplete support's modification. The Rh-Acy-POL catalyst showed $\mathrm{BE}$ for $\mathrm{Cl} 2 \mathrm{p}$ at traces level as shown in Table 2. Both results are in agreement with ICP-AES characterization and confirm the Rh catalyst immobilization on the polymer's surface.

Table 2 includes also display the surface Rh wt $\%$ and $F$ factor determined by XPS employing the same methodology reported by Román-Martínez et $a .^{\mathbf{4 0 , 4 1}}$ The values of $F$ indicate a high dispersion degree in the location of the complex in both supports (where $F=1$ correspond to the homogeneous distribution of the complex in the porous materials ${ }^{\mathbf{4 1}}$ ). These results are in agreement with the decrease on the $S_{\mathrm{BET}}$ as a consequence of $\mathrm{Rh}$ complex anchoraged in the resins.

For both Rh supported catalysts, P 2p BE at 132.2-132.4 eV were detected. Typically, these values are assigned to $\left(\mathrm{Ph}_{2}\right)_{2} \mathrm{P}$ coordinated with $\mathrm{Rh}(\mathrm{I})$ species. ${ }^{38}$ The main advantage in the alkyl-phosphine immobilization is the $\mathrm{P}$ atom oxidation by $\mathrm{O}_{2} \cdot{ }^{36,42,43}$ Unfortunately, it was not possible to distinguish between coordinated-phosphine $(\mathrm{P}-\mathrm{Rh})$ and phosphine oxide $(\mathrm{P}=\mathrm{O})$ due to closer $\mathrm{BE}$ of the most intense peak $\mathrm{P} 2 \mathrm{p}$ at 132.0132.6 eV (ref. 38 and 41) for $\mathrm{P}-\mathrm{Rh}$ and $132.8-133.2 \mathrm{eV}$ for $\mathrm{P}=\mathrm{O}^{43}$ However, Rh-Alk-POL catalysts showed an $\mathrm{Rh} / \mathrm{P}$ atomic ratio lower than in the nominal content meaning that unreacted/ oxidized diphenylphopshine species are present, in agreement with ${ }^{31} \mathrm{P}$ solid-state NMR characterization.

\subsection{Catalytic activity}

Fig. 3 shows the catalytic data obtained for diphenylphosphinebased $\mathrm{Rh}$ (I) catalyst at 30 minutes of reaction (see the synthesis details in ESI $\dagger$ ) for hydrogenation of styrene (STY). Firstly, for comparison purposes a reference $\left[\mathrm{Rh}(\mathrm{COD})_{2}\right] \mathrm{BF}_{4}$ catalyst

Table 2 XPS data of the immobilized Rh catalysts

\begin{tabular}{|c|c|c|c|c|c|c|c|c|c|}
\hline \multirow[b]{2}{*}{ Sample } & \multirow{2}{*}{$\begin{array}{l}\mathrm{Rh} 3 \mathrm{~d}_{5 / 2} \\
(\mathrm{eV})\end{array}$} & \multirow{2}{*}{$\begin{array}{l}\mathrm{Cl} 2 \mathrm{p} \\
(\mathrm{eV})\end{array}$} & \multirow{2}{*}{$\begin{array}{l}\text { P 2p } \\
\text { (eV) }\end{array}$} & \multirow{2}{*}{$\begin{array}{l}\text { C 1s } \\
(\mathrm{eV})\end{array}$} & \multirow[b]{2}{*}{$\mathrm{Rh} / \mathrm{P}$} & \multirow[b]{2}{*}{$\mathrm{Cl} / \mathrm{C}$} & \multicolumn{3}{|c|}{$\begin{array}{l}\text { Rh content } \\
(\mathrm{wt} \%)\end{array}$} \\
\hline & & & & & & & $\mathrm{XPS}^{a}$ & ICP & $F^{b}$ \\
\hline Rh-Alk-POL & 308.9 & 198.4 & 132.2 & 284.8 & 0.33 & 0.009 & 1.60 & 0.67 & 2.4 \\
\hline Rh-Acy-POL & 309.1 & Trace & 132.4 & 284.8 & 0.45 & - & 2.95 & 0.95 & 3.1 \\
\hline
\end{tabular}

${ }^{a} \mathrm{Rh}$ content determined by XPS. $.^{40,41} b=\mathrm{Rh} w \mathrm{wt} \%$ (XPS)/Rh wt\% (ICP).

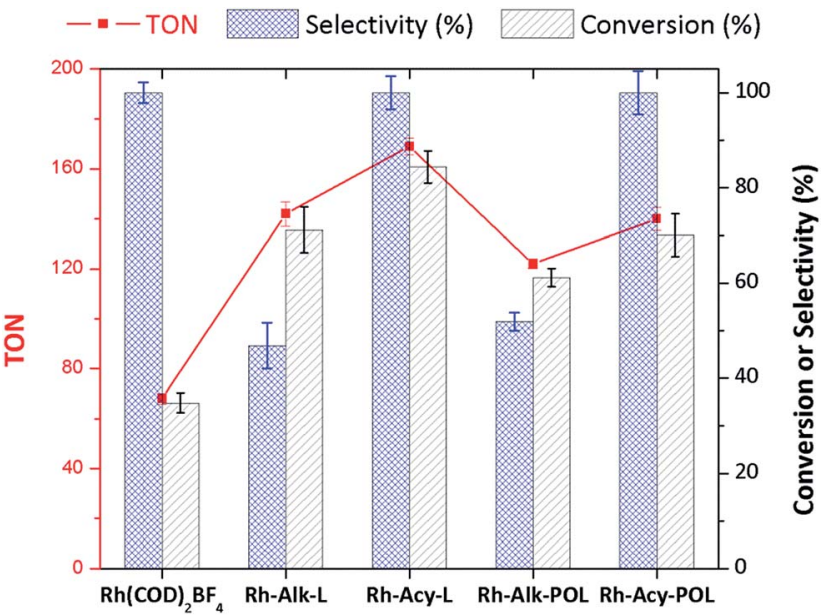

Fig. 3 Hydrogenation of STY with Rh-based catalysts. Reaction conditions: $25^{\circ} \mathrm{C}, 5.0$ bar $\mathrm{H}_{2}$, at STY/Rh $=200$ mole ratio in methanol $(25 \mathrm{~mL})$ at $30 \mathrm{~min}$ of reaction. The homogeneous catalysts were prepared in situ adding Alk- or Acy-L into the reactor at diphosphine/ $\mathrm{Rh}=0.5$ mole ratio. For the supported catalysts $100 \mathrm{mg}$ of hybrid catalyst were used. The selectivity corresponds to EBZ production.

without the diphenylphosphine ligand was used. As can be observed in Fig. 3 the conversion obtained after 30 minutes of reaction $(35 \%)$ shows the low activity for $\left[\mathrm{Rh}(\mathrm{COD})_{2}\right] \mathrm{BF}_{4}$ catalyst. Secondly, homogeneous catalyst Rh-Alk-L and Rh-Acy-L references were prepared in situ from the diphenylphosphinesbased ligands and the $\left[\mathrm{Rh}(\mathrm{COD})_{2}\right] \mathrm{BF}_{4}$ precursor. These catalysts showed high activity under the same reaction conditions. However, a different selectivity on the products distribution was detected. The STY hydrogenation could be following the reaction pathways which are shown in Scheme 2. The $\left[\mathrm{Rh}(\mathrm{COD})_{2}\right]$ $\mathrm{BF}_{4}$ and Rh-diphosphine catalysts are highly chemoselective towards alkene hydrogenation. ${ }^{44-47}$ The over-hydrogenated product could be attributed to the presence of metallic Rh nanoparticles indicating that the electronic state of rhodium in the complex was modified during the hydrogenation process. $^{\mathbf{4 2 , 4 8 , 4 9}}$ TEM analysis was employed to confirm that

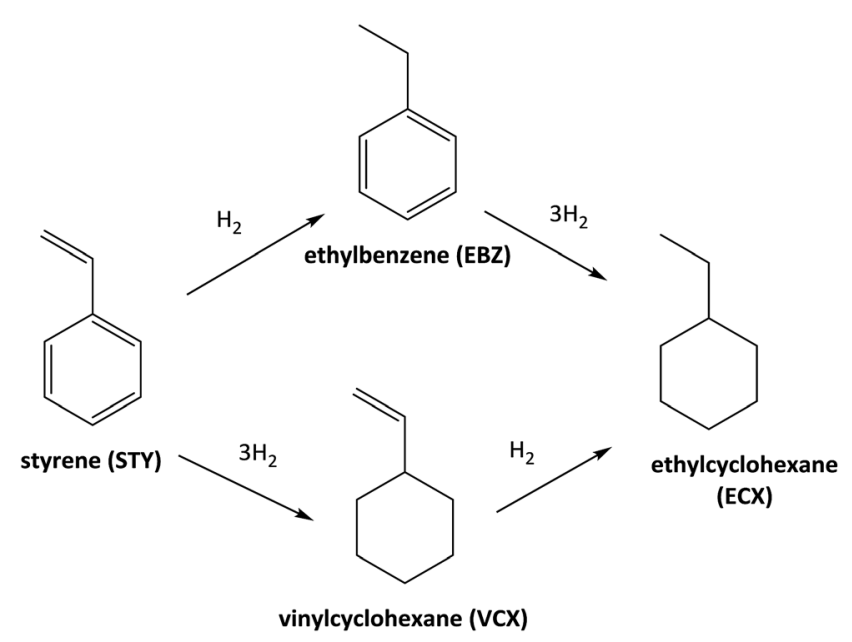

Scheme 2 Reaction pathways in the catalytic hydrogenation of STY. 

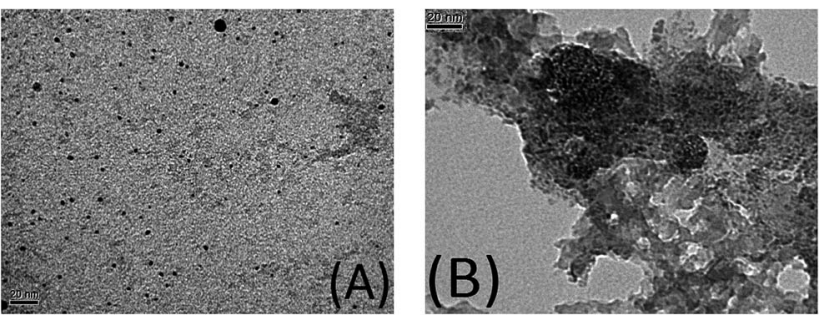

Fig. 4 TEM characterization post-reaction. (A) Rh-Alk-L and (B) RhAlk-POL.

metallic Rh NPs are formed, for both homogeneous and heterogeneous diphenylphosphine-based $\mathrm{Rh}(\mathrm{I})$ catalyst, as shown in Fig. 4.

Only Rh-Alk-L catalysts showed the presence of metallic Rh NPs mainly ascribed to Alk-L ligand which decrease the stability of the Rh-complex catalysts under reaction conditions at 30 minutes compared with Acy-L. This behavior could be explained by the nature of the $\mathrm{N}$ atom on the ligand, where the amide nature of Acy-L ligand provide greater stability to the Rh-center decreasing its reducibility under $\mathrm{H}_{2}$ atmosphere. Finally, RhAlk-L catalyst showed ECX and EBZ as hydrogenation products while Rh-Acy-L achieved the maximum selectivity to EBZ (100\%).

A similar trend for the immobilized Rh-complex catalyst was detected. Both systems showed a decrease in the activity compared with the homogeneous catalysts which is

Table 3 XPS and ICP characterization post-reaction for Rh-Acy-POL catalyst

\begin{tabular}{llll}
\hline Sample & $\begin{array}{l}\text { Rh 3d } \\
(\mathrm{eV})\end{array}$ & $\begin{array}{l}\mathrm{P} 2 \mathrm{p} \\
(\mathrm{eV})\end{array}$ & $\begin{array}{l}\text { Rh content } \\
(\mathrm{wt} \%)\end{array}$ \\
\hline Fresh & 309.1 & 132.4 & 0.95 \\
Used without STY & 309.0 & 132.3 & 0.96 \\
Used after last run & 308.9 & 132.2 & 0.92
\end{tabular}

\section{4 meta-Substituted styrene hydrogenation}

We also investigated the hydrogenation of meta-substituted styrene molecules ( $m$-X-STY where X: $\mathrm{NH}_{2}, \mathrm{CH}_{3}, \mathrm{Cl}$ or $\mathrm{NO}_{2}$ ) over Rh-Acy-POL catalyst as shown in Table 4 . All the kinetics showed pseudo-first order's kinetics with respect to the $m$-X-STY substrates consumption and only produced the hydrogenation
(A)

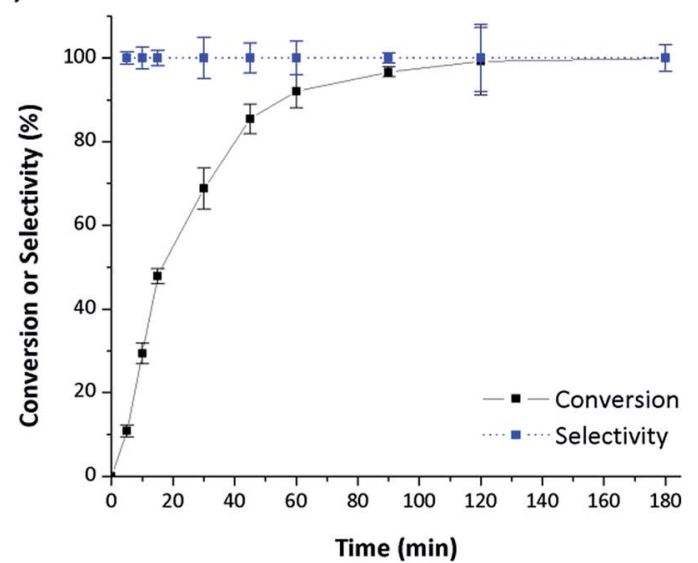

(B)

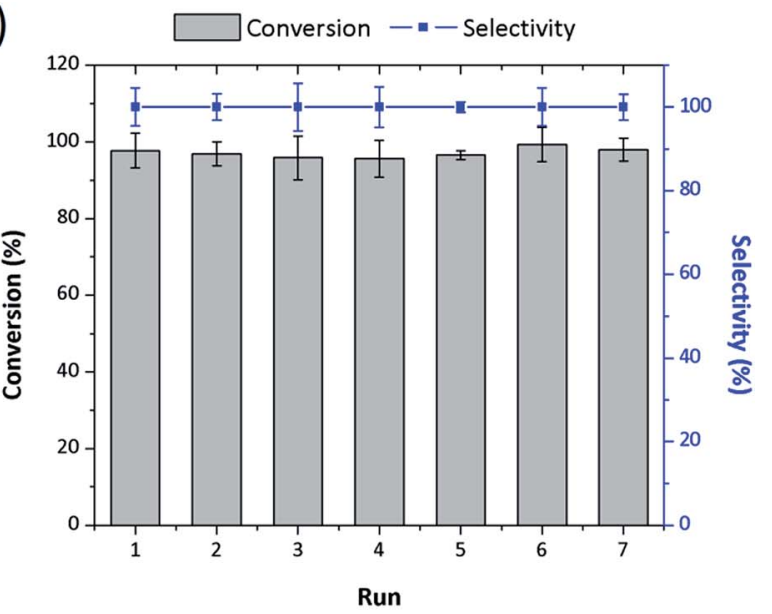

Fig. 5 Reaction profiles for hydrogenation of STY and recycles studies using Rh-Acy-POL as catalyst. (A) Conversion level vs. time and (B) recycles runs at 120 minutes. Reaction conditions: $25^{\circ} \mathrm{C}, 5.0$ bar $\mathrm{H}_{2}$, at STY/Rh $=200$ mole ratio in methanol $(25 \mathrm{~mL})$. 
Table 4 Catalytic data for meta-substituted substrates hydrogenation over Rh-Acy-POL catalyst. Reaction conditions: $25^{\circ} \mathrm{C}, 5.0 \mathrm{bar}_{2}$, at $m-X-S T Y / R h=200$ mole ratio in methanol $(25 \mathrm{~mL})$

\begin{tabular}{|c|c|c|c|c|}
\hline Substrate & $\begin{array}{l}\text { Conversion }^{a} \\
{[ \pm 2 \%]}\end{array}$ & $\begin{array}{l}\text { Selectivity }^{b} \\
{[ \pm 2 \%]}\end{array}$ & $\begin{array}{l}k_{m \text {-x-STY }}{ }^{c} \\
{\left[\mathrm{~h}^{-1} \mathrm{mmol}_{\left.\mathrm{Rh}^{-1}\right]}{ }^{-1}\right.}\end{array}$ & $\sigma_{\text {meta }}{ }^{d}$ \\
\hline STY & 68 & 100 & 29 & - \\
\hline$m-\mathrm{NO}_{2}-\mathrm{STY}$ & 83 & 100 & 46 & 0.71 \\
\hline$m$-Cl-STY & 76 & 100 & 39 & 0.37 \\
\hline$m-\mathrm{CH}_{3}-\mathrm{STY}$ & 65 & 100 & 26 & -0.07 \\
\hline$m-\mathrm{NH}_{2}-\mathrm{STY}$ & 60 & 100 & 22 & -0.16 \\
\hline
\end{tabular}

${ }^{a} 30 \mathrm{~min}$ of reaction. ${ }^{b}$ Calculated for vinyl-group hydrogenation. ${ }^{c}$ Pseudo-first-order constant. ${ }^{d}$ Extract from Hansch et al. ${ }^{50}$

of alkene moiety avoiding the hydrogenation of $-\mathrm{NO}_{2}$ or hydrodechlorination for $m-\mathrm{NO}_{2}$-STY and $m$-Cl-STY, respectively.

The kinetic data displayed dependence between reaction rate and the electronic nature of the substituent in meta position. Assuming the pseudo-first model, catalytic rate constant $\left(k_{m \text {-X-STY }}\right.$ and $\left.k_{\text {STY }}\right)$ were calculated as shown in Table 4 . The

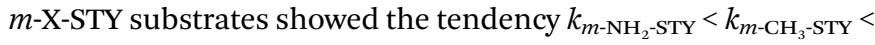

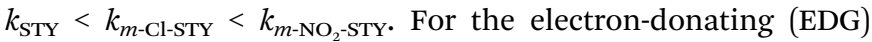
groups the catalytic rate constant showed lower values in comparison with $m$-styrenes derivates with the electron withdrawing group (EWG). With these results, a correlation analysis between electronic nature of substrates and the experimental catalytic constants was performed. The kinetic data was correlated with Hammett $\sigma_{\text {meta }}$ constant, as shown in Fig. 6, since previous report has showed a linear correlation between $\sigma_{\text {Hammett }}$ of $m$-substituted nitroarenes and its the catalytic constants for hydrogenation reaction catalyzed by metallic $\mathrm{Rh}$ NPs. ${ }^{3}$ The empirical values of $\sigma_{\text {meta }}$ were defined by Hammett from the ionization constants of benzoic acids as: $\sigma_{\text {meta }}: \log \left(K_{\mathrm{x}}\right)$ $-\log \left(K_{\mathrm{H}}\right)$ where $K_{\mathrm{H}}$ is the ionization constant for benzoic acid in water at $25{ }^{\circ} \mathrm{C}$ and $K_{\mathrm{x}}$ is the corresponding constant for a meta-substituted benzoic acid. The values used in our adjustment were compiled by Hansch et al..$^{50}$ The rational of this analysis was based on the hydrogenation reaction mechanism proposed for Halpern. ${ }^{51}$ The $\left[\mathrm{Rh}(\text { diene }) \mathrm{L}_{n}\right]^{+}$catalysts operates in 4 stages: (1) oxidative addition of $\mathrm{H}_{2}$ promoting $\mathrm{Rh}(\mathrm{I}) \rightarrow \mathrm{Rh}(\mathrm{III})$, (2) the substrate insertion into the coordination cloud, (3) migratory insertion of a hydride to the alkene substrate and (4) the reductive elimination of the hydrogenated substrate to retrieve $\mathrm{Rh}(\mathrm{I})$ in the catalyst. It is well known that the rate determining step (RDS) is the insertion of a hydride on the $\mathrm{C}=\mathrm{C}$ alkene moiety. ${ }^{26}$

The hydride insertion could induce a carbanion character on $\mathrm{C}=\mathrm{C}$ bond at the transition state, hence the presence of EWG increases the affinity for the hydride, enhancing the catalytic activity and instead EDG decrease the hydrogenation rate of the vinyl group. A good linear correlation $\left(R^{2}=0.9698\right)$ between the experimental $\log \log \left(k_{m \text {-X-STY }} / k_{\mathrm{STY}}\right)$ and the $\sigma_{\text {meta }}$ was found. The following logarithmic equation describes the relationship between $k_{m \text {-X-STY }} / k_{\mathrm{STY}}$ and the electronic nature of the substrates, showing to be a statistically accurate model with $99 \%$ confidence $(p=0.0072)$.

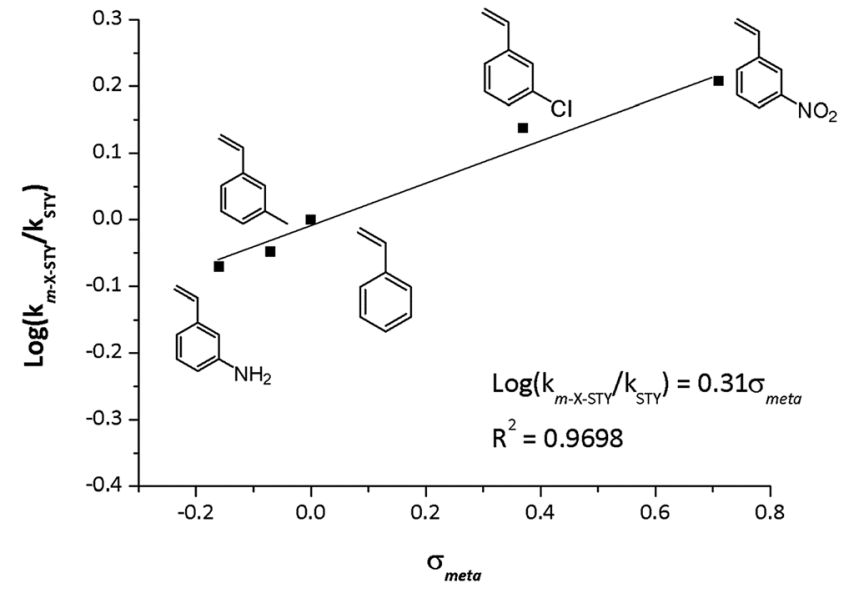

Fig. 6 Experimental $\log \left(k_{m-X-S T Y} / k_{\text {STY }}\right) \quad$ vs. $\sigma_{\text {meta }}$ constants of substrates. Reaction conditions: $25^{\circ} \mathrm{C}, 5.0$ bar $\mathrm{H}_{2}$, at $m-\mathrm{X}-\mathrm{STY} / \mathrm{Rh}=$ 200 mole ratio in methanol $(25 \mathrm{~mL})$.

\section{Conclusions}

New heterogeneous rhodium-diphenylphosphine supported catalysts on porous resins have been prepared and characterized. The rhodium catalysts based in the precursor $\mathrm{N}, \mathrm{N}$-bis(2chloroethyl)-2-propen-1-amine was a less stable than $N, N$ bis(2-chloroethyl)acrylamide and this difference was reasonably attributed to the instability of phosphinated ligand under the reaction conditions. As shown by TEM analysis, on the immobilized $N, N$-bis(2-(diphenylphosphino)ethyl)-2-propen-1-amine based catalyst, the rhodium(I) species are converted to rhodium $(0)$ nanoparticles preventing the selective hydrogenation reaction. The amide based catalyst showed an excellent catalytic performance during the hydrogenation of styrene producing ethylbenzene as the only reaction product. The catalyst was highly stable at the reactions conditions and no-leaching was detected, even after 7 consecutive reaction cycles. Finally, the catalytic activity of this system for the hydrogenation of $m$-substituted styrene showed a chemoselective hydrogenation of alkene function due to the electronic nature of substituent group. Thus, substituted styrene with electron-withdrawing groups showed very high activities, while styrene derivatives with electron-donating groups presented lower activities. This catalyst proved to be active and highly chemoselective for the hydrogenation of alkenes and its immobilization via covalent immobilization on porous resin support may indeed be used as a strategy leading to stable catalysts.

\section{Acknowledgements}

The authors thank CONICYT for the financial support (FONDECYT postdoctoral 3140130 and FONDECYT Initiation 11160468). We also gratefully acknowledge the help of Dr José Luis G. Fierro of the Instituto de Catálisis y Petroleoquímica (ICP-CSIC) - Sustainable Energy and Chemistry Group (Marie Curie 2 Cantoblanco Madrid - Spain) for the XPS analysis. 


\section{References}

1 C. M. Eichenseer, B. Kastl, M. A. Pericàs, P. R. Hanson and O. Reiser, ACS Sustainable Chem. Eng., 2016, 4, 2698-2705.

2 E. Verde-Sesto, E. Merino, E. Rangel-Rangel, A. Corma, M. Iglesias and F. Sánchez, ACS Sustainable Chem. Eng., 2016, 4, 1078-1084.

3 C. H. Campos, E. Rosenberg, J. L. G. Fierro, B. F. Urbano, B. L. Rivas, C. C. Torres and P. Reyes, Appl. Catal., A, 2015, 489, 280-291.

4 J. Lu and P. H. Toy, Chem. Rev., 2009, 109, 815-838.

5 C. Jimeno, S. Sayalero and M. A. Pericàs, in Heterogenized Homogeneous Catalysts for Fine Chemicals Production: Materials and Processes, ed. P. Barbaro and F. Liguori, Springer Netherlands, Dordrecht, 2010, pp. 123-170.

6 I. E. Ertas, M. Gulcan, A. Bulut, M. Yurderi and M. Zahmakiran, J. Mol. Catal. A: Chem., 2015, 410, 209-220.

7 A. Popa, R. Ene, D. Visinescu, E. S. Dragan, G. Ilia, S. Iliescu and V. Parvulescu, J. Mol. Catal. A: Chem., 2015, 408, 262270.

8 M. T. Gokmen and F. E. Du Prez, Prog. Polym. Sci., 2012, 37, 365-405.

9 J. Xiong, C. Hang, J. Gao, Y. Guo and C. Gu, Chem. Eng. J., 2014, 254, 276-282.

10 E. Breysse, C. Pinel and M. Lemaire, Tetrahedron: Asymmetry, 1998, 9, 897-900.

11 F. J. L. Heutz and P. C. J. Kamer, Dalton Trans., 2016, 45, 2116-2123.

12 Y. Jun, X. Rongnan and Y. Juntan, J. Appl. Polym. Sci., 1989, $38,45-54$.

13 J. Wei, X. Y. Bai and J. Yan, Macromolecules, 2003, 36, 49604966.

14 J. Wei, X. Zhao and J. Yan, J. Appl. Polym. Sci., 2004, 92, 26812688.

15 F. Bildik, E. Yavuz, T. Sismanoglu and B. Filiz Senkal, Macromol. Symp., 2015, 352, 66-71.

16 I.-H. Park, J. M. Rhee and Y. S. Jung, Angew. Makromol. Chem., 1999, 267, 27-34.

17 A. Blasig, J. Tang, X. Hu, S. P. Tan, Y. Shen and M. Radosz, Ind. Eng. Chem. Res., 2007, 46, 5542-5547.

18 L. Canali, E. Cowan, H. Deleuze, C. L. Gibson and D. C. Sherrington, J. Chem. Soc., Perkin Trans. 1, 2000, 2055-2066.

19 R. Drake, D. C. Sherrington and S. J. Thomson, React. Funct. Polym., 2004, 60, 65-75.

20 S. Bulut, Z. Fei, S. Siankevich, J. Zhang, N. Yan and P. J. Dyson, Catal. Today, 2015, 247, 96-103.

21 J. Su and J.-S. Chen, Microporous Mesoporous Mater., 2017, 237, 246-259.

22 G. Busca, Heterogeneous Catalytic Materials, Elsevier, Amsterdam, 2014, pp. 297-343.

23 F. Jiang, J. Cai, B. Liu, Y. Xu and X. Liu, RSC Adv., 2016, 6, 75541-75551.

24 P. Pospiech, J. Chojnowski, U. Mizerska, T. Makowski, K. Strzelec and N. Sienkiewicz, Appl. Organomet. Chem., 2016, 30, 399-407.
25 C. Liu, J. Liu, S. Yang, C. Cao and W. Song, ChemCatChem, 2016, 8, 1279-1282.

26 L. A. Oro and D. Carmona, The Handbook of Homogeneous Hydrogenation, Wiley-VCH Verlag GmbH, 2006, pp. 2-30.

27 E. de Wolf, A. L. Spek, B. W. M. Kuipers, A. P. Philipse, J. D. Meeldijk, P. H. H. Bomans, P. M. Frederik, B.-J. Deelman and G. van Koten, Tetrahedron, 2002, 58, 3911-3922.

28 N. E. Leadbeater and M. Marco, Chem. Rev., 2002, 102, 32173274.

29 R. Haag, W. Bannwarth, F. Koç, F. Michalek and L. Rumi, Synthesis, 2005, 3362-3372.

30 P. B. Webb and D. J. Cole Hamilton, Phosphorus(III) Ligands in Homogeneous Catalysis: Design and Synthesis, John Wiley \& Sons, Ltd, 2012, pp. 497-532.

31 C. D. Wagner, L. E. Davis, M. V. Zeller, J. A. Taylor, R. H. Raymond and L. H. Gale, Surf. Interface Anal., 1981, 3, 211-225.

32 V. Nieminen, A. Taskinen, M. Hotokka and D. Y. Murzin, J. Catal., 2007, 245, 228-236.

33 E. Toukoniitty, P. Mäki-Arvela, N. Kumar, T. Salmi and D. Y. Murzin, Catal. Today, 2003, 79-80, 189-193.

34 C. H. Campos, C. C. Torres, A. B. Dongil, D. Ruiz, J. L. G. Fierro and P. Reyes, Catal. Today, 2014, 235, 226-236.

35 S. Sahoo, H. Lundberg, M. Edén, N. Ahlsten, W. Wan, X. Zou and B. Martín-Matute, ChemCatChem, 2012, 4, 243-250.

36 K. J. Stanger, J. W. Wiench, M. Pruski and R. J. Angelici, J. Mol. Catal. A: Chem., 2003, 195, 63-82.

37 C. R. Hilliard, N. Bhuvanesh, J. A. Gladysz and J. Blumel, Dalton Trans., 2012, 41, 1742-1754.

38 M. C. Román-Martínez, J. A. Díaz-Auñón, C. SalinasMartínez de Lecea and H. Alper, J. Mol. Catal. A: Chem., 2004, 213, 177-182.

39 C. M. Standfest-Hauser, T. Lummerstorfer, R. Schmid, H. Hoffmann, K. Kirchner, M. Puchberger, A. M. Trzeciak, E. Mieczyńska, W. Tylus and J. J. Ziółkowski, J. Mol. Catal. A: Chem., 2004, 210, 179-187.

40 L. J. Lemus-Yegres, M. C. Román-Martínez, I. Such-Basáñez and C. Salinas-Martínez de Lecea, Microporous Mesoporous Mater., 2008, 109, 305-316.

41 M. Pérez-Cadenas, L. J. Lemus-Yegres, M. C. RománMartínez and C. Salinas-Martínez de Lecea, Appl. Catal., A, 2011, 402, 132-138.

42 D. Dehe, L. Wang, M. K. Müller, G. Dörr, Z. Zhou, R. N. Klupp-Taylor, Y. Sun, S. Ernst, M. Hartmann, M. Bauer and W. R. Thiel, ChemCatChem, 2015, 7, 127-136.

43 R. Yerushalmi, J. C. Ho, Z. Fan and A. Javey, Angew. Chem., Int. Ed., 2008, 47, 4440-4442.

44 K. J. Stanger, Y. Tang, J. Anderegg and R. J. Angelici, J. Mol. Catal. A: Chem., 2003, 202, 147-161.

45 A. Crosman and W. F. Hoelderich, Catal. Today, 2007, 121, 130-139.

46 P. Kleman and A. Pizzano, Tetrahedron Lett., 2015, 56, 69446963.

47 R. Sayah, M. Le Floch, E. Framery and V. Dufaud, J. Mol. Catal. A: Chem., 2010, 315, 51-59. 
48 H.-Y. Jiang and X.-X. Zheng, Appl. Catal., A, 2015, 499, 118123.

49 J. L. Castelbou, P. Blondeau, C. Claver and C. Godard, RSC Adv., 2015, 5, 97036-97043.
50 C. Hansch, A. Leo and R. W. Taft, Chem. Rev., 1991, 91, 165195.

51 J. Halpern, Inorg. Chim. Acta, 1981, 50, 11-19. 